Наносистели, нанолатеріали, нанотехнології Nanosistemi, Nanomateriali, Nanotehnologii 2018 , т. 16 , № 1 , сc. $23-30$ (c) 2018 ІМФ (Інститут металофізики ім. Г. В. Курдюмова НАН України) Надруковано в Україні. Фотокопіювання дозволено тільки відповідно до ліцензі

PACS numbers: 78.40.Ri, 81.05.ub, 82.20.Wt, 82.30.Nr, 87.15.ak, 87.15.ap

\title{
A Molecular Container for Anti-Aromatic System Based on Double-Walled Carbon Nanotube: in Silico Study
}

O. V. Mykhailenko ${ }^{1}$, Yu. I. Prylutskyy ${ }^{1}$, I. V. Komarov ${ }^{1}$,

A. V. Strungar ${ }^{2}$, O. O. Mykhailenko ${ }^{1}$, and V. L. Osetskyi ${ }^{1}$

${ }^{1}$ Taras Shevchenko National University of Kyiv,

64, Volodymyrska Str.,

UA-01601 Kyiv, Ukraine

${ }^{2}$ Vernadsky National Library of Ukraine,

3, Holosiivskyi Ave.,

UA-03039 Kyiv, Ukraine

There has been studied the formation of a 'Host-Guest' type carcerand with a double-walled carbon nanotube (DWCNT) as a 'host' and an unstable anti-aromatic cyclobutadiene as a 'guest'. By employing the methods of MM+, PM3 and Monte Carlo, there has been investigated the positioning of cyclobutadiene molecules in a DWCNT depending on intercalant concentration and temperature. At that, the deformation vibrations of the DWCNT crystal grate do not exceed $0.017 \mathrm{~nm}$, and the vibrations of the intercalant molecules do not exceed $0.025 \mathrm{~nm}$, that provides for configuration and conformation stability of the studied nanosystem. When initially heated from 0 to $\cong 283 \mathrm{~K}$, the system energy grows gradually, then rises sharply between $290-300 \mathrm{~K}$ and $380-400 \mathrm{~K}$, then, with the temperature growth, it reaches the plateau, which proves its high stability up to $\cong 430 \mathrm{~K}$. There have been calculated UV-spectrum of a DWCNT depending on the intercalant concentration and association constant of the 'DWCNT-intercalant' nanosystem.

Вивчено утворення карцеранду типу «господар-гість» 3 двостінною вуглецевою нанотрубкою (ДВНТ) як «господар» і нестабільним антиароматичним циклобутадієновим як «гість». 3 використанням метод MМ+, PM3 та Монте-Карло досліджено позиціонування молекул циклобутадієну у ДВНТ, залежно від їх концентрації та температури. При цьому деформаційні коливання гратниці ДВНТ не перевищують 0,017 нм, а коливання інтеркальованих молекул $-0,025$ нм, що забезпечує конфігураційну та конформаційну стійкість досліджуваної наносистеми. 3 нагріванням від 0 до $\cong 283$ К енергія системи зростає поступово, потім різко зростає між 290-300 К та 380-400 К, а далі зі зростанням температури вона досягає плато, що доводить її високу стабільність за тем- 
ператури у $\cong 430$ К. Розраховано УФ-спектер ДВНТ, залежно від концентрації інтеркалянта, та константу асоціяції наносистеми «ДВНТінтеркалянт».

Изучено образование карцеранда типа «хозяин-гость» с двухстенной углеродной нанотрубкой (ДУНТ) в качестве «хозяина» и нестабильным антиароматическим циклобутадиеном в качестве «гостя». С использованием методов МM+, РМ3 и Монте-Карло исследовано позиционирование молекул циклобутадиена в ДУНТ в зависимости от их концентрации и температуры. При этом деформационные колебания решётки ДУНТ не превышают 0,017 нм, а колебания интеркалированных молекул - 0,025 нм, что обеспечивает конфигурационную и конформационную устойчивость исследуемой наносистемы. С нагреванием от 0 до $\cong 283$ К энергия системы растёт постепенно, дальше резко возрастает между 290-300 K и 380-400 K, а затем с ростом температуры она достигает плато, что свидетельствует о её высокой стабильности при температуре $\cong 430$ К. Рассчитаны УФ-спектр ДУНТ в зависимости от концентрации интеркалянта и константа ассоциации наносистемы «ДУНТ-интеркалянт».

Key words: double-walled carbon nanotube, cyclobutadiene, intercalation, modelling, association constant.

Ключові слова: двостінна вуглецева нанотрубка, циклобутадієн, інтеркаляція, моделювання, константа асоціації.

Ключевые слова: двухстенная углеродная нанотрубка, циклобутадиен, интеркаляция, моделирование, константа ассоциации.

(Received 20 January 2018; after revision, 24 January 2018)

\section{INTRODUCTION}

Unusual physical and chemical properties of nanocarbon systems have been the subject of keen interest lately. The electronic band structure of carbon nanotubes (CNTs), along with their small size and low dimension, are responsible for their unique electrical, mechanical, and thermal properties [1-3]. Semi-conductor CNTs are the most promising candidates in the field of nanoelectronics, while metallic CNTs have aroused a lot of research interest for their applicability due to high thermal stability, high thermal conductivity, and large current carrying capability. What is more, the chemical and physical modification of nanocarbon systems enables to reveal their new extraordinary features. Thus, intercalation with molecules allows to change the Fermi level position, relative electron and hole concentrations, without considerable changes in energyband structure of source CNTs [4-8]. 
On the other hand, unique optical, electrical and magnetic behaviour of multi-walled CNTs can be enhanced and diversified in case of synthesizing the complexes with other compounds what will expand opportunities of obtaining new materials as effective elements for photo- and magnetosensitive devices [9-13].

The aim of this work is to study the structure of intercalated cyclobutadiene double-walled CNT (DWCNT) when heating by the MM+, PM3 and Monte Carlo, to calculate the UV-spectrum of DWCNT depending on intercalant concentration, and to determine the association constant of the 'DWCNT-intercalant' nanosystem.

\section{THEORETICAL MODEL AND METHODS OF RESEARCH}

The initial structure was a $(5,5) @(10,10)$ DWCNT having 270 carbon atoms. Intercalation of this DWCNT assumes placing the intercalant inside the (5.5) CNT and into the intertubular space [13].

The intercalant is the cyclobutadiene molecules. The subject of this calculation is their relative positions, their orientation relatively the CNT walls, their behaviour in the intertubular space and the system as a whole, as well as the quantity characteristics of bonding with the DWCNT at temperature change (Fig. 1).

In the model considered, the interaction potential (Lennard-Jones potential) between $\mathrm{C}-\mathrm{C}$ atoms (see Eq. (1)) directly mated the pair potential of high energy of atomic excitation [14], and it was described by the Born-Mayer equation within the range $0-0.4 \mathrm{~nm}$ of effective interaction radius (see Eq. (2)):

$$
U(r)=4 \varepsilon\left[\left(\frac{\sigma}{r}\right)^{12}-\left(\frac{\sigma}{r}\right)^{6}\right],
$$
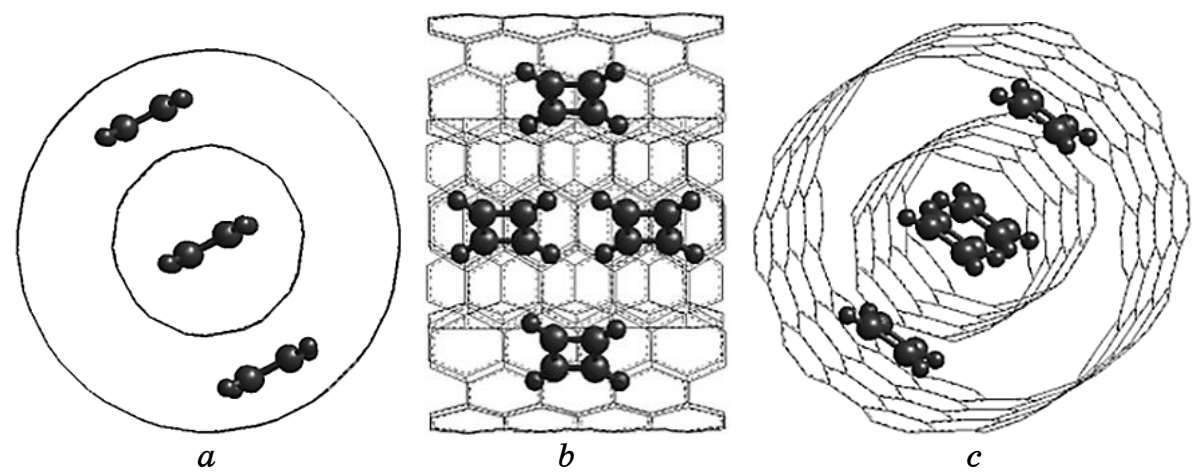

Fig. 1. Initial structure of the 'DWCNT-cyclobutadiene' nanosystem: $(a)$, (b) orthogonal projections; (c) side view. 
where $r$-distance between particle centres; $\varepsilon$-depth of potential pit; $\sigma$-distance, at which the interaction energy is equal to zero (parameters $\varepsilon$ and $\sigma$ characterise the atoms of corresponding substances);

$$
U(r)=A \exp (-r / b),
$$

where $A, b$-constants, for every pair of colliding particles.

To describe the atom interaction at a distance smaller than 0.2 $\mathrm{nm}$, we have used the Tersoff-Brenner potential of interatomic interaction [15].

Total potential energy of system $U$ is expressed as a sum of bonding energies for all pairs of atoms forming this system:

$$
U=\sum_{i} \sum_{j>i}\left[V_{R}\left(r_{i j}\right)-B_{i j}^{*} V_{R}\left(r_{i j}\right)\right],
$$

where $r_{i j}$-distance between $i$ and $j$ atoms; $V_{R}\left(r_{i j}\right)$-exponential function included into the Morse-type potential, which corresponds to the energies of attraction and repulsion between the atoms; $B_{i j}{ }^{*}-$ the function expressing the dependence of binding energy of the $i$ and $j$ atoms on the angles $\theta_{i j k}$ between the $i-j$ bond and close $i-k$ and $j-k$ bonds.

To describe the atom interaction at a distance greater than 0.21 $\mathrm{nm}$, we have applied the Tersoff-Brenner potential of interatomic interaction [15] along with the Ziegler-Biersack-Litmark pair potential [14]. The length of $\mathrm{C}-\mathrm{C}$ bonds in a DWCNT was $0.139 \mathrm{~nm}$; the $\mathrm{C}-\mathrm{C}$ interaction ('DWCNT-cyclobutadiene' interaction) was described by the Lennard-Jones pair potential [16] with potential interaction energy of $0.12 \mathrm{eV}$. The modelled period of one excitation cascade was $2 \mathrm{ps}$, and the energy conservation law in every calculation cycle was correlated within $0.15 \%$. The initial coordinates of the intercalant were selected in conformity with the law of random numbers.

To calculate the association constant of the carcerplex formed, there was applied the modified Benes-Hilderbrand method [17] that accounts the data on maximum DWCNT absorption values at various intercalant concentrations in the UV-spectra. All the calculations were made within the temperature range $0-500 \mathrm{~K}$.

\section{RESULTS AND DISCUSSIONS}

Modelling of the 'DWCNT-intercalant' nanosystem resulted in such statements. First, the two intercalant molecules in the intertubular space form a system, which is resistant to temperatures up to $\cong 290$ $\mathrm{K}$, being completely and quickly extruded at higher temperatures. 


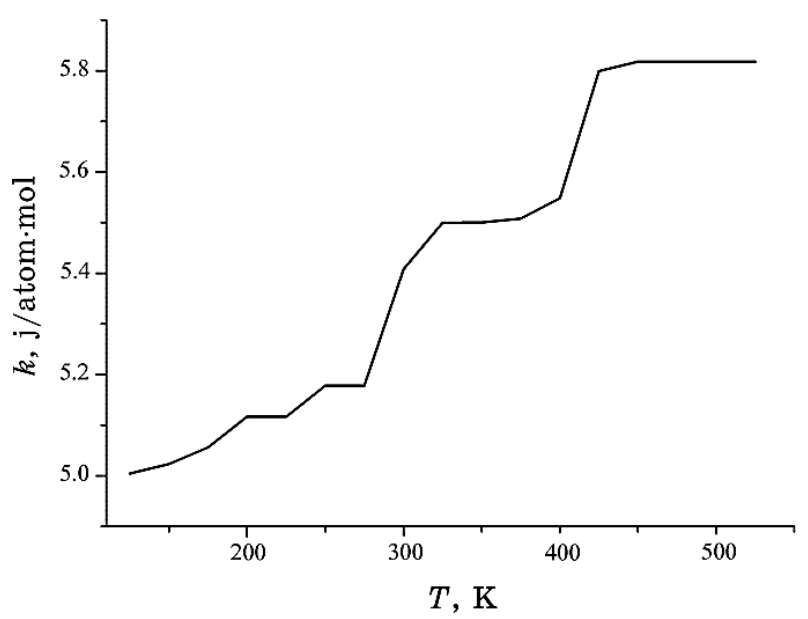

Fig. 2. Temperature dependence of the 'DWCNT-cyclobutadiene' model nanosystem.

Second, two cyclobutadiene molecules being in the inner (5.5) CNT are stable up to $\cong 380 \mathrm{~K}$.

The studied nanosystem (see Fig. 2) proved to be rather heatresistant in a wide temperature range (up to $\cong 400 \mathrm{~K}$ ). At that, the deformation vibrations of the DWCNT crystal grate do not exceed $0.015 \mathrm{~nm}$, and the vibrations of the intercalant molecules do not exceed $0.025 \mathrm{~nm}$ that provides for configuration and conformation stability of the nanosystem.

Temperature dependence of the model-nanosystem energy is shown in Fig. 2. As shown, when initially heated from 0 to $\cong 290 \mathrm{~K}$ and $300-380 \mathrm{~K}$, the system energy grows gradually, then rises sharply between $290-300 \mathrm{~K}$ and $380-400 \mathrm{~K}$, then, with temperature growth, it reaches the plateau that proves its high stability.

The modelling performed allows determining the following dynamics of the intercalated DWCNT structure when heated: when being initially heated to $\cong 290 \mathrm{~K}$, the system remains rather stable; there is no extrusion of the intercalant molecules (Fig. 3). There are observed vibrational and rotational capabilities of bonds and angles of a DWCNT and cyclobutadiene molecules.

It should be noted that this variant of the model suggested allows seeing thermodynamic selectivity of physical and chemical sorptiondesorption. At the temperature range 0-290 K, there appears physical sorption while chemisorption is observed at higher temperature figures $(300-380 \mathrm{~K})$ that is peculiar or $\pi-\pi$ interactions of cyclobutadiene aromatic cyclic and quasi-aromatic DWCNT systems.

Moreover, simultaneous presence of donor/acceptor feature of the DWCNT intertube space as a result of positive and negative Gaussi- 


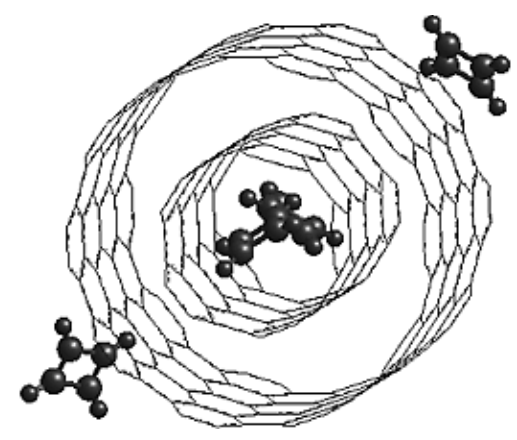

Fig. 3. Screenshot of configurational change of the 'DWCNT-intercalant' nanosystem when heated.

an curvature makes it possible to regulate orientation of intercalant donor and acceptor edges that allows viewing it as a potential molecular switch.

Finally, theoretical calculations of UV-absorption spectra of the (5.5)@(10.10) DWCNT (Fig. 4) depending on the intercalant concentration in terms of the modified Benes-Hilderbrand method shows that the association constant of the system studied is of 183.5 $1 \cdot \mathrm{mol}^{-1}$ with the calculation accuracy $k_{\text {cor }} \geq 0.98$,

$$
C_{\text {guest }}\left(A_{0}-A\right)=\frac{1}{K_{\text {ass }} \Delta \varepsilon} \frac{1}{C_{\text {host }}}+\frac{1}{\Delta \varepsilon},
$$

where $C_{\text {guest }}$ and $C_{\text {host }}$ - 'guest' and 'host' concentration, respectively; $A_{0}$ and $A$-DWCNT and 'DWCNT-cyclobutadiene' absorption, respectively; $\Delta \varepsilon$-change of molar extinction coefficient.

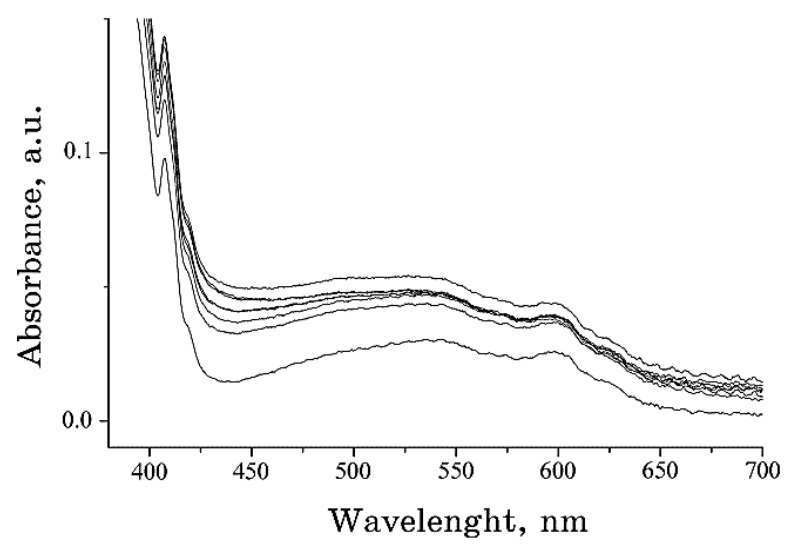

Fig. 4. Calculated UV-absorption spectrum of the DWCNT depending on the intercalant concentration. 


\section{CONCLUSION}

There has been found out the type of cyclobutadiene molecule arrangement on the inner surface as well as in the intertube space of the $(5,5) @(10,10)$ DWCNT. The calculations allow proving that the 'DWCNT-intercalant' nanosystem is rather stable at temperature up to $290 \mathrm{~K}$ that provides reliability and stability of the process of intercalant synthesis under conditions regular for this procedure. However, at further heating (above $300 \mathrm{~K}$ ), there is observed gradual intercalant extrusion out of the intertube space as well as thermodynamic stabilisation of the system containing the intertube intercalant only. There has been theoretically calculated the association constant of the 'DWCNT-cyclobutadiene' nanosystem, namely, $183.5 \mathrm{l} \cdot \mathrm{mol}^{-1}$.

\section{REFERENCES}

1. I. Takesue, J. Haruyama, N. Kobayashi, S. Chiashi, S. Maruyama, T. Sugai, and H. Shinohara, Phys. Rev. Lett., 96: 057001 (2006).

2. A. G. Nasibulin, P. V. Pikhitsa, H. Jiang, D. P. Brown,

A. V. Krasheninnikov, A. S. Anisimov, P. Queipo, A. Moisala, D. Gonzalez, G. Lientschnig, A. Hassanien, S. D. Shandakov, G. Lolli, D. E. Resasco, M. Choi, D. Tománek, and E. I. Kauppinen, Nat. Nanotechnol., 2: 156 (2007).

3. Q. Liu, R. Wencai, Z.-G. Chen, L. Yin, F. Li, H. Cong, and H.-M. Cheng, Carbon, 47: 731 (2009).

4. I. V. Ovsiyenko, T. Len, L. Matzui, Yu. Prylutskyy, P. Eklund, F. Le Normand, U. Ritter, and P. Scharff, Physica E, 37: 78 (2007).

5. G. E. Grechnev, V. A. Desnenko, A. V. Fedorchenko, A. S. Panfilov, Yu. A. Kolesnichenko, L. Yu. Matzui, M. I. Grybova, Yu. I. Prylutskyy, U. Ritter, and P. Scharff, Low Temp. Phys., 36: 1086 (2010).

6. U. Ritter, P. Scharff, G. E. Grechnev, V. A. Desnenko, A. V. Fedorchenko, A. S. Panfilov, Yu. I. Prylutskyy, and Yu. A. Kolesnichenko, Carbon, 49: 4443 (2011).

7. U. Ritter, N. G. Tsierkezos, Yu. I. Prylutskyy, L. Yu. Matzui, V. O. Gubanov, M. M. Bilyi, and M. O. Davydenko, J. Mater. Sci., 47, No. 5: 2390 (2012).

8. T. Len, I. Ovsiienko, L. Matzui, I. Berkutov, I. Mirzoiev, Yu. Prylutskyy, V. Andrievskii, I. Mirzoiev, Yu. Komnik, G. Grechnev, Yu. Kolesnichenko, R. Hayn, and P. Scharff, Phys. Status Solidi B, 252, No. 6: 1402 (2015).

9. O. P. Matyshevska, A. Yu. Karlash, Ya. V. Shtogun, Y. V. Benilov, A. Y. Kirgizov, K. O. Gorchinskyy, E. V. Buzaneva, Y. I. Prylutskyy, and P. Scharff, Mater. Sci. Engineer. C, 15: 249 (2001).

10. T. Durkop, B. M. Kim, and M. S. Fuhrer, J. Phys: Condensed Matter, 16, No. 18: 553 (2004).

11. O. Mykhailenko, D. Matsui, Yu. Prylutskyy, F. Normand, P. Eklund, and P. Scharff, J. Mol. Model., 13, No. 1: 283 (2007).

12. O. V. Mykhailenko, Yu. I. Prylutskyy, I. V. Komarov, A. V. Strungar, and 
N. G. Tsierkezos, Mat.-wiss. u. Werkstofftech., 47, Nos. 2-3: 203 (2016).

13. O. V. Mykhailenko, Yu. I. Prylutskyy, I. V. Komarov, and A. V. Strunhar, Nanoscale Res. Lett., 11: 128 (2016).

14. D. C. Rapaport, The Art of Molecular Dynamics Simulation (Cambridge, UK: Cambridge University Press: 1995).

15. J. Tersoff, Phys. Rev., 39: 5566 (1989).

16. S. Dorfman, K. C. Mundim, D. Fuks, A. Berner, and D. E. Ellis, Mat. Sci. and Eng., 15: 191 (2001).

17. P. Qureshi, R. Varshney, and S. Singh, Spectrochim Acta A, 50: 1789 (1994). 